\title{
HAKIKAT OTONOMI DAERAH DALAM SISTEM KETATANEGARAAN DI INDONESIA Roy Marthen Moonti
}

\author{
Mahasiswa Program Doktor Ilmu Hukum Pascasarajana UMI Makassar \\ email : anzar2017@ymail.com
}

\begin{abstract}
The essence of regional autonomy in the state system in Indonesia is the authority given to local governments to regulate and manage their own affairs and interests of the community in accordance with the legislation in force. Keywords : Autonomy and Governance System in Indonesia.
\end{abstract}

\begin{abstract}
Abstrak
Inti dari otonomi daerah dalam sistem negara di Indonesia adalah kewenangan yang diberikan kepada pemerintah daerah untuk mengatur dan mengelola urusan dan kepentingan masyarakat mereka sendiri sesuai dengan peraturan perundang-undangan yang berlaku.

Kata kunci: Otonomi dan Sistem Pemerintahan di Indonesia
\end{abstract}

\section{A. PENDAHULUAN}

Sebagai aplikasi dari Pasal 18, 18A, dan 18B Undang Undang Dasar Negara Republik Indonesia Tahun 1945 UUD NRI Tahun 1945),yang substansinya secara tegas dan transparan memberikan pengakuan tentang keberadaan pemerintahan daerah (provinsi, dan kabupaten/kota), dengan asas desentralisasi yang melahirkan otonomi daerah pada masing-masing daerah otonom.

Konsekuensi yang ditimbulkan berkenaan dengan penyelenggaraan pemerintahan negara, menyebabkan keseluruhan wilayah Negara Republik Indonesia (NRI) dibagi atas daerah provinsi dan di dalam daerah provindi dibagi lagi atas daerah kabupaten dan kota. Masing-masing daerah provinsi, daerah kabupaten dan kota diberikan hak otonomi untuk mengatur dan mengurus urusan serta kepentingan daerahnya. Sedang penyerahan hak otonomi kepada setiap daerah, haruslah didasarkan atas undang-undang sebagai ciri khas dari suatu negara hukum (Pasal 1 ayat (3) UUD NRI Tahun 1945).

Penerapan perinsip otonomi daerah tidak statis, tetapi senantiasa bersifat dinamis, karena mengikuti perkembangan sistem ketatanegaraan Indonesia.Bahkan dinamisasi penerapan prinsip otonomi daerah, senantiasa mendapat pengaruh dari perubahan konstitusi, terutama implikasinya pada perubahan regulasi yang mengatur pemerintahan daerah, mulai dari UU Nomor 1 Tahun 1945 jo UU Nomor 22 Tahun 1948 dan Staatblad Indonesia Timur Nomor 44 Tahun 1950 menganut sistem otonomi materiil. Selanjutnya UU Nomor 1 Tahun 1957 menganut sistem otonomi riil, diganti dengan UU Nomor 18 Tahun 1965 dengan pemberian otonomi seluas-luasnya.

Vol. 19 No. 2 November 2017 
Perkembangan selanjutnya dengan diundangkannya Undang-Undang Nomor 5 Tahun 1974 Tentang Pokok-Pokok Pemerintahan Di Daerah,yang menganut sistem otonomi nyata dan bertanggung jawab, yang diera reformasi Pemerintah mengundangkan UU Nomor 22 Tahun 1999 Tentang Pemerintahan Daerah, yang menganut prinsip otonomi luas, nyata dan bertanggung jawab. Kemudian diganti dengan UU Nomor 32 Tahun 2004 dengan menganut prinsip otonomi yang seluas-luasnya dan terakhir dengan UU Nomor 23 Tahun 2014.

Secara mutatis mutandis perkembangan ketatanegaraan mempengaruhi perkembangan otonomi daerah.Namun demikian, setiap daerah adalah bagian integral dari pusat, sehingga tidak dikenal adanya negara di dalam negara.Menurut gagasan dan konsep hukum yang tertuang di dalam UU Nomor 23 Tahun 2014 joPerpu No. 2 Tahun 2014, bahwa otonomi daerah hanya ada pada daerah otonom. Artinya, otonomi daerah hanya ada pada pemerintah daerah berdasarkan asas desentralisasi, tetapi tidak ada pada daerah yang didasarkan atas asas dekonsentrasi, karena dekonsentrasi itu sendiri merupakan perpanjangan tangan dari pemerintah pusat di daerah, yang pelaksanaan tugas pekerjaannya senantiasa mendapat dukungan dari pemerintah pusat berupa aparat dan pendanaan.

Berkenaan uraian di atas, menjadi menarik untuk dikaji lebih mendalam berkenaan dengan hakikat otonomi daerah dalam sistem ketatanegaraan.

\section{B. ANALISIS DAN PEMBAHASAN}

Otonomi Daerah di Indonesia telah diat ur dalam undang-undang, yang dalam perkembangannya telah mengalamiperubahan dan terakhir dengan Undang-Undang Nomor 23 Tahun 2014 Tentang Pemerintahan Daerah. Otonomi daerah pada dasarnya merupakan upaya untuk mewujudkan tercapainya salah satu tujuan negara, yaitu peningkatan kesejahteraan masyarakat melalui perataan pelaksanaan pembangunan dan hasil-hasilnya. Daerah memiliki kewenangan membuat kebijakan daerah untuk memberi pelayanan, peningkatan peran serta prakarsa dan pemberdayaan masyarakat yang bertujuan pada peningkatan kesejahteraan rakyat.

\section{Asas-Asas Penyelenggaraan Otonomi Daerah}

Dalam rangka pembagian kekuasaan negara (secara vertikal) dibentuklah daerahdaerah yang bersifat otonom dengan bentuk dan susunan pemerintahannya yang diatur kemudian dalam undang-undang. Dengan demikian terdapat pemerintah pusat disatu sisi, dan pemerintah daerah disisi lain. Hubungan di antara keduanya dibingkai dalam sistem negara kesatuan.Pemerintah pusat menyelenggarakan pemerintahan nasional dan pemerintah daerah menyelenggarakan pemerintahan daerah.Dalam hubungan inilah pemerintah pusat perlu melaksanakan pembagian kekuasaan kepada pemerintah daerah, melaluidesentralisasi.

Sebagai salah satu sendi negara yang demokratis (democratische-rechtsstaat), desentralisasi merupakan pilihan yang tepat dalam rangka menjawab berbagai persoalan yang dihadapi negara dan bangsa, pada masa sekarang dan yang akan datang. Dalam kenyataannya, desentralisasi merupakan antitesa dari sentralisasi penyelenggaraan pemerintahan.Dalam perkembangannya dua kutub itu tidak jarang 
diletakkan secara saling berlawanan.Pada hal di dalam paham negara kesatuan, keliru jika mempertentangkan keduanya.Artinya, kedua kutub tersebut saling melengkapi dan membutuhkan dalam kerangka yang ideal sebagai sendi negara demokratis.

Pentingnya desentralisasi pada esensinya, ialah agar persoalan yang kompleks yang dilatar belakangi oleh berbagai faktor hetoregen dan kekhususan daerah dapat ditangani dengan baik.Berbagai budaya, agama, adat-istiadat dan juga wilayah yang sangat luas tidaklah mungkin ditangani semuanya oleh pemerintahan pusat.Demikian juga sebaliknya tidaklah mungkin semua persoalan dalam penyelenggaraan negara didesentralisasikan kepada daerah, dengan alasan menjalankan prinsip demokrasi.Karena itu, pengendalian dan pengawasan pusat sebagai cerminan dari sentralisasi, tetap dipandang mutlak sepanjang tidak melemahkan, bahkan memandulkan prinsip demokrasi.Sebagai konsep desentralisasi tumbuh dan berkembang seiring dengan tuntutan dan kebutuhan negara demokrasi.

Amrah Muslimin dalam Agus Santoso ${ }^{1}$ membedakan tiga bentuk desentralisasi, yaitu desentralisasi politik, desentralisasi fungsional dan desentralisasi kebudayaan. Desentralisasi politik adalah pelimpahan kewenangan dari pemerintah pusat yang menimbulkan hak mengurus kepentingan rumah tangga sendiri bagi badan-badan politik di daerah-daerah yang dipilih oleh rakyat dalam daerah-daerah tertentu.Desentralisasi fungsional, adalah pemberian hak dan kewenangan pada golongan-golongan untuk mengurus macam kepentingan dalam masyarakat, baik terkait ataupun tidak pada suatu daerah tertentu seperti mengurus kepentingan irigasi bagi golongsan tani dalam suatu daerah. Desentralisasi kebudayaan, adalah memberikan hak pada golongan-golongan kecil dalam masyarakat untuk menyelenggarakan kebudayaannya sendiri,seperti pendidikan, agama dan lain-lain.

Irawan Soejito ${ }^{2}$ membagi bentuk desentralisasi teritorial, desentralisasi fungsional dan desentralisasi administrasi lazim disebut dengan dekonsentrasi.Dekonsentrasi, adalah pelimpahan sebagian kewenangan pemerintah pusat kepada alat perlengkapan atau organnya sendiri di daerah. Sedangkan yang dimaksud desentralisasi territorial, adalah desentralisasi kewenangan yang dilakukan pemerintah kepada suatu badan umum. Desentralisasi fungsional, adalah pemberian kewenangan dari fungsi pemerintahan negara atau daerah untuk diselenggarakan oleh suatu organ, atau badan ahli yang khusus dibentuk untuk itu.Dekonsentrasi diartikan sebagai pemberian kekuasaan dari atas kebawah di dalam rangka kepegawaian guna kelancaran pekerjaan semata-mata.

Desentralisasi dalam arti ketatanegaraan, adalah pelimpahan kekuasaan pemerintahan dari pusat kepada daerah-daerah yang mengurus rumah tangganya sendiri (daerah otonomi). Desentralisasi adalah cara atau sistem untuk mewujudkan asas demokrasi yang memberikan kesempatan kepada rakyat untuk ikut serta dalam

\footnotetext{
${ }^{1}$ Agus Santoso, Menyingkap Tabir Otonomi Daerah di Indonesia, Pustaka Pelajar, Yogyakarta, hal. 123

${ }^{2}$ Irawan Soejito, Hubungan Pemerintah Pusat dan Pemerintah Daerah. Jakarta, Bina Aksara, 1991, hal. 50
} 
pemerintahan negara. Dengan demikian, maka desentralisasi dapat dibagi dua macam, yaitu:

1. Dekonsentrasi, yaitu pelimpahan kekuasaan dari alat perlengkapan negara tingkat yang lebih diatas kepada yang lebih dibawah guna melancarkan pekerjaan di dalam melaksanakan tugas pemerintahan, misalnya pelimpahan kekuasaan dan wewenang menteri kepada gubernur.

2. Desentralisasi ketatanegaraan atau disebut juga desentralisasi politik, yaitu pelimpahan kekuasaan perundang-undangan dan pemerintahan kepada daerahdaerah otonom di dalam lingkungannya. Didalam desentralisasi politik, rakyat dengan mempergunakan saluran tertentu ikut serta di dalam pemerintahan, dengan batas wilayah daerah masing-masing .

Desentralisasi ketatanegaraan dapat dibagi lagi dalam dua macam yaitu:

a. Desentralisasi territorial, yaitu pelimpahan kekuasaan untuk mengatur dan mengurus rumah tangga daerah masing-masing.

b. Desentralisasi fungsional, yaitu pelimpahan kekuasaan untuk mengatur dan mengurus satu atau beberapa kepentingan tertentu. Di dalam desentralisasi semacam ini, dikehendaki agar kepentingan-kepentingan tertentu diselenggarakan oleh golongan yang bersangkutan sendiri.

Sebagai konsekuensi pelaksanaan asas desentralisasi menciptakan local self government, dan dekonsentrasi menciptakan local state government atau field administration. Dilys M. Hill dalam Agus Santoso ${ }^{3}$ mencontohkan di Inggeris "In England local government has been defendend as a vital andintegral part of democracy. Local self government is valued because it is just, it safeguard and anhances the ciotizen's right and it is an imporant setting for political education"..(Di Inggris pemerintahan daerah telah lama dianggap sebagai hal yang pokokdan bagian yang tak terpisahkan dari demokrasi.Pemerintahan daerah otonom mempunyai makna yang penting, karena dapat melindungi dan memperjuangkan hak-hak warga negara dan juga dalam membangun pendidikan warga negara).

Indonesia sendiri keperluan atas pemerintah daerah seperti provinsi, kabupaten dan kota setidaknya untuk meningkatkan akuntabilitas. Pemerintahan lokal secara global semakin dilihat sebagai suatu agenpembangunanyang penting, dan seharusnya juga diketahui bahwa tingkat ini merupakan yang paling penting bagi partisipasi "akar masalah", karena yang paling dapat menanggapi kondisi, dan kebutuhan setempat. Dalam alur pikir yang tidak jauh berbeda, Ateng Syafruddin ${ }^{4}$ menegaskan bahwa di daerah merupakan suatu keharusan, yakni bagi suatu daerah yang telah mendapatkan otonomi.

Betapa pentingnya pemerintahan daerah dalam suatu negara, maka tidak heran jika hal itu dianggap menjadi suatu kebutuhan dan keharusan bagi setiap negara dengan tidak melihat bentuk negara apakah negara federal atau negara kesatuan.

\footnotetext{
${ }^{3}$ Agus Santoso, Op. Cit, hal 127

${ }^{4}$ Agus Santoso, Ibid Hal 134
} 
Pemerintahan daerah adalah hal yang universal, karena terdapat beberapa ciri-ciri sebagai berikut:

1. Segala urusan yang diselenggarakan merupakan urusan rumah tangga sendiri, sehingga berupa urusan-urusan tersebut ditegaskan secara terperinci.

2. Penyelenggaraan pemerintahan dilaksanakan oleh alat-alat perlengkapan yang seluruhnya bukan terdiri dari pada pejabat pusat tetapi pegawai pemerintah daerah.

3. Penanganan segala urusan itu seluruhnya diselenggarakan atas dasar inisiatif atau kebijaksanaan sendiri.

4. Hubungan pemerintah pusat dengan pemerintah daerah yang mengurus rumah tangga sendiri adalah hubungan pengawasan saja.

5. Seluruh penyelenggaraannya pada dasarnya dibiayai dari sumber keuangan sendiri.

Penyelenggaraan pemerintahan daerah melalui sistem desentralisasi yang berintikan pada otonomi yang merupakan syarat mutlak di dalam negara demokrasi. Lebih tegas lagi dikatakan bahwa desentralisasi bukan sekedar pemencaran wewenang (spretiding van bevoegdheid), tetapi juga mengandung pembagian kekuasaan (scheiding van machten) untuk mengatur dan mengurus penyelenggaraan pemerintahan negara antara pemerintah pusat dengan pemerintah daerah. Hal itu disebabkan desentralisasi senantiasa berkaitan dengan status mandiri atau otonom, sehingga setiap pembicaraan mengenai desentralisasi akan selalu dipersamakan dengan otonomi.

Desentralisasi adalah pemberian otonomi kepada masyarakat dalam wilayah tertentu. Kaitan desentralisasi dan otonomi daerah seperti itu, terlukis dalam penyataan bahwa desentralisasi dan otonomi daerah merupakan dua sisi dari satu mata uang. Otonomi adalah sebuah tatanan ketatanegaraan bukan saja tatanan administrasi negara.Sebagai tatanan ketatanegaraan, otonomi berkaitan dengan dasar- dasar bernegara dan susunan organisasi negara.

Istilah otonomi mempunyai makna kebebasan atau kemandirian, tetapi bukan kemerdekaan.Kebebasan yang terbatas atau kemandirian itu, adalah wujud pemberian kesempatan yang harus dipertanggung jawabkan. Dalam pemberiantanggung jawab terkandung dua unsur yaitu:

a. Pemberian tugas dalam arti sejumlah pekerjaan yang harus diselesaikan serta kewenangan untuk melaksanakannya.

b. Pemberian kepercayaan berupa kewenangan untuk memikirkan dan menetapkan sendiri bagaimana menyelesaikan tugas itu.

Bagir Manan dalam Agus Santoso ${ }^{5}$ mengemukakan bahwa otonomi adalah kebebasan dan kemandirian satuan pemerintahan lebih rendah untuk mengatur dan mengurus sebagian urusan pemerintahan.Urusan pemerintahan yang boleh diatur dan diurus secara bebas dan mandiri itu menjadi, atau merupakan urusan rumah tangga

\footnotetext{
${ }^{5}$ Ibid hal 125
} 
satuan pemerintahan yang lebih rendah tersebut.Kebebasan dan kemandirian merupakan hakikat isi otonomi.

Kebebasan dan kemandirian dalam otonomi bukan kemerdekaan.Kebebasan dan kemandirian itu, adalah kebebasan dan kemandirian dalam ikatan kesatuan yang lebih besar.Otonomi sekedar subsistem dari sistem kesatuan yang lebih besar.Dari segi hukum tata negara, khususnyateori bentuk negara, otonomi adalah subsistem dari negara kesatuan.Otonomi adalah fenomena negara kesatuan, segala pengertian dari isimateri otonomi adalah pengertian dan isi negera kesatuan.Negara kesatuan merupakan landasan dari pengertian dan isi otonomi.

Benyamin Husain ${ }^{6}$ mengartikan otonomi hampir paralel dengan pengertian demokrasi, yaitu pemerintahan oleh dari dan untuk rakyat dibagian wilayah nasional suatu negara melalui lembaga-lembaga pemerintahan yang secara formal berada di luar pemerintahan pusat. Bahkan otonomi dapat diberi arti secara luas ataupun dalam arti sempit. Dalam arti luas, otonomi mencakup pula tugas pembantuan, sebab baik otonomi maupun tugas pembantuan sama-sama mengandung kebebasan dan kemandirian. Dalam otonomi, kebebasan dan kemandirian itu meliputi asas maupun cara menjalankannya. Sedangkan dalam tugas pembantuan, kebebasan dan kemandirian terbatas pada cara menjalankannya.

Otonomi dan demokrasi merupakansatu kesatuan semangat sebagai bentuk pemerintahan yang menempatkan rakyat sebagai penentu yang utama dalam negara.Apabila ditinjau dari mekanisme, otonomi daerah dalam negara kesatuan diberikan oleh pemerintah pusat kepada pemerintah daerah.Jadi pemerintah daerah hanya menerima penyerahan kewenangan dari pemerintah pusat.Hal itu berbeda dengan otonomi daerah di negara federal, karena di sini otonomi daerah telah melekat pada negara-negara bagian.Dengan demikian, urusan yang dimiliki oleh pemerintah federal pada hakikatnya adalah urusan yang diserahkan oleh negara bagian.Dalam negara kesatuan, kewenangan cenderung berada di pemerintahan pusat, sedangkan dalam negara federal berada di pemerintah daerah. Hal itu menyebabkan otonomi pemerintah daerah dinegara kesatuan seperti Indonesia, lebih banyak bergantung kepada polical will pemerintah pusat, yaitu sampai sejauh mana pemerintah pusat mempunyai niat baik untuk memberdayakan local government, melalui pemberian wewenang yang lebih besar.

Desentralisasi akan melahirkan otonomi dan keduanya merupakan pelaksanaan dari prinsip negara demokrasi. Secara teoritik, kemampuan pemerintah antara lain terbentuk melalui penerapan asas desentralisasi, yaitu adanya pelimpahan wewenang dari tingkat pusat kepada tingkat daerah secara hirarkis, melalui pelimpahan wewenang itulah pemerintah pada tingkat daerah diberi kesempatan untuk memngambil inisiatif, dan mengembangkan kreaktivitas, mencari solusi terbaik atas setiap masalah yang dihadapi dalam pelaksanaan tugas sehari-hari. Selain itu, desentralisasi dapat juga dipahami sebagai penyerahan wewenang politik dan perundang-undangan untuk perencanaan, pengambilan keputusan, dan manajemen

\footnotetext{
${ }^{6}$ Ibid hal 126
} 
pemerintahan dari pemerintah pusat kepada daerah / wilayah administrasi Negara, atau kepada kelompok-kelompok fungsional atau organisasi non pemerintahan atau swasta.

Menurut penulis mengenai pemerintah melaksanakan desentralisasi kekuasaan, disebabkan karena adanya alasan-alasan yang mendasar pada kondisi ideal yang diinginkan, sekaligus memberikan landasan filosofis untuk penyelenggaraan pemerintahan daerah sesuai sistem pemerintahan yang dianut oleh negara kesatuan seperti Indonesia. Adapun alasan-alasan yang dimaksud adalah sebagai berikut:

1. Dilihat dari sudut politik sebagai permainan kekuasaan desentralisasi dimaksudkan untuk mencegah penumpukan kekuasaan pada satu pihak saja, yang pada akhirnya dapat menimbulkan tirani;

2. Dalam bidang politik, penyelenggaraan desentralisasi dianggap sebagai tindakan pendemokrasian, untuk menarik rakyat ikut serta dalam pemerintahan dan melatih diri dalam mempergunakan hak-hak demokrasi;

3. Dari sudut teknik organisatoris pemerintahan, alasan mengadakan pemerintahan daerah adalah semata-mata untuk mencapai suatu pemerintahan yang efisien. Apa yang dianggap lebih utama untuk diurus oleh pemerintah setempat, pengurusannya diserahkan kepada daerah.

4. Dari sudut kultural, desentralisasi perlu diadakan supaya perhatian dapat sepenuhnya ditumpahkan kepada kekhususan suatu daerah, seperti geografi, keadaan penduduk, kegiatan ekonomi, watak kebudayaan atau latar belakang sejarahnya.

5. Dari sudut kepentingan pembangunan ekonomi, desentralisasi diperlukan karena pemerintah daerah dapat lebih banyak dan secara langsung membantu pembangunan tersebut.

Berdasarkan uraian tersebut di atas, maka untuk mewujudkan hal tersebut, tidak mungkin pelayanan terhadap rakyatnya terpusat pada satu pemerintahan (Pemerintah pusat), tetapi harus didistribusikan pada penyelenggara pemerintahan di daerah. Karena itu, untuk melayani dan mewujudkan tujuannya, dibentuklah daerah-daerah sebagaimana di atur dalam Pasal 18, Pasal 18A, Pasal 18B UUD NRI Tahun 1945.

Pembentukan pemerintahan daerah bertujuan untuk mencapai efektivitas dan efesien dalam pelayanan kepada masyarakat. Bung Hatta menjelaskan bahwa wujud kedaulatan rakyat sebagai pernyataan dari pemerintahan rakyat, adalah dalam keadaan seluruhnya atau dalam bagian-bagiannya, rakyat memerintah dirinya sendiri. Kedaulatan yang dilakukan oleh rakyat daerah bukan kedaulatan yang keluar dari pokoknya, melainkan kedaulatan yang datang dari kedaulatan rakyat yang lebih di atas.Dengan demikian, kedaulatan yang dimiliki oleh rakyat daerah ini, tidak boleh bertentangan dengan garis-garis besar yang telah ditetapkan dalam garis-garis haluan negara.

Otonomi yang diselenggarakan di Negara Kesatuan Republik Indonesia dipengaruhi oleh faktor-faktor yang mendasarinya, yaitu: 
a. Keragaman bangsa Indonesia dengan sifat-sifat istimewa pada berbagai golongan, tidak memungkinkan pemerintahan diselenggarakan secara seragam;

b. Wilayah Indonesia yang berpulau-pulau dan luas dengan segala pembawaan masing-masing memerlukan cara-cara penyelenggaraan yang sesuai dengan keadaan dan sifat-sifat dari berbagai pulau tersebut;

c. Desa dan berbagai persekutuan hukum merupakan salah satu sendi yang ingin dipertahankan dalam susunan pemerintahan Negara;

d. Pancasila dan UUD NRI Tahun 1945 menghendaki susunan pemerintahan yang demokratis. Desentralisasi adalah salah satu cara mewujudkan tatanan demokrasi tersebut;

e. Efesiensi dan efektivitas merupakan salah satu ukuran keberhasilan organisasi. Indonesia yang luas dan penduduk yang banyak dan beragam memerlukan cara penyelenggaraan pemerintahan negara yang menjamin efesiensi dan efektivitas. Dengan membagi-bagi penyelenggaraan pemerintahan dalam satuan-satuan yang lebih kecil, efesiensi dan efektivitas tersebut dapat tercapai.

Menurut peraturan perundang-undangan yang berlaku, daerah otonom dibagi pada tiga pola daerah, yaitu provinsi, kabupaten dan kota. Disamping sebagai daerah otonom, provinsi ditetapkan sebagai daerah administratif dalam rangka desentralisasi.Karena itu, gubernur memiliki peranan ganda, yaitu gubernur sebagai kepala daerah, dan perangkat/wakil pemerintah pusat. Hal ini tercantum dalam UU Nomor 23 Tahun 2014 Pasal 2 ayat (1) bahwa Negara Kesatuan Republik Indonesia dibagi atas daerah provinsi dan daerah kabupaten dan kota. Selanjutnya Pasal 3 ayat (1) dirumuskan bahwa " Daerah Provinsi dan Kabupaten/Kota sebagaimana dimaksud dalam Pasal 2 ayat (1) merupakan daerah dan masing-masing mempunyai pemerintahan daerah".

Hubungan antara daerah otonom dan pemerintahan pusat merupakan hubungan antara organisasi, bukan hubungan intra organisasi.Adapun hubungan antara daerah otonom merupakan hubungan yang setara, tidak bersifat hierarkis.Hubungan antara pemerintah pusat, provinsi dan kabupaten/kota yang menurut UU Nomor 5 Tahun 1974 hanya merupakan perpanjangan tangan pemerintah pusat di daerah, berdasarkan UU Nomor 23 Tahun 2014 tentang Pemerintahan Daerah, bahwa pemerintah daerah (provinsi, kabupaten dan kota) dapat mengambil tanggung jawab yang lebih besar dalam pelayanan umum kepada masyarakat setempat untuk mengatur dan mengurus rumah tangganya sesuai dengan kepentingan masyarakat. Dengan demikian otonomi daerah adalah hak, wewenang dan kewajiban daerah otonom untuk mengatur dan mengurus sendiri.Urusan pemerintahan dan kepentingan masyarakat setempat dalam sistem Negara Kesatuan Republik Indonesia. Adapun daerah otonom, adalah kesatuan masyarakat hukum yang mempunyai batas-batas wilayah yang berwenang mengatur dan mengurus urusan pemerintahan dan kepentingan masyarakat setempat menurut prakarsa sendiri berdasarkan aspirasi masyarakat dalam sistem Negara Kesatuan Republik Indonesia. 
Secara prinsipil ada dua hal yang tercakup dalam otonomi, yaitu hak, wewenang untuk memanajemen daerah dan tanggung jawab terhadap kegagalan dalam memanajemen daerahnya.Sementara daerah dalam arti local state government, adalah pemerintah di daerah yang merupakan perpanjangan tangan dari pemerintah pusat.Dengan adanya otonomi, daerah diharapkan lebih mandiri dalam menentukan seluruh kegiatannya dan pemerintah pusat diharapkan tidak terlalu aktif mengatur daerah. Pemerintahan daerah diharapkan mampu memainkan peranannya dalam membuka peluang memajukan daerah, tanpa intervensi dari pihak lain, yang disertai dengan pertanggungjawaban publik serta kepada pemerintah pusat sebagai konsekuensi dari Negara Kesatuan Republik Indonesia.

\section{Desentralisasi}

Negara Republik Indonesia yang merupakan negara kesatuan memilih sistem penyelenggaraan pemerintahan dengan sistem desentralisasi. Penerapan sistem ini di dasarkan pada berbagai pertimbangan, antara lain luasnya wilayah negara dan banyaknya kepentingan yang harus diselenggarakan oleh pemerintah pusat dan bertambah majunya masyarakat, sehingga pemerintah tidak dapat mengurus semua kepentingan itu dengan baik, tanpa berpegang pada asas kedaerahan dalam melakukan pemerintahan.

Jika diperhatikan posisi geografis dan demografis wilayah Indonesia, tampak kesulitan yang besar jika sistem penyelenggaraan pemerintahan negara dilaksanakan secara sentralistik.Sistem ini tidak mungkin diterapkan di wilayah yang sangat luas, lengkap dengan beragam budaya dan adat istiadat yang hidup.Untuk mencapai tujuan negara dengan tidak mengurangi keutuhan negara kesatuan, digunakan sistem desentralisasi.

Tujuan utama desentralisasi adalah : (a) tujuan politik yang ditujukan untuk menyalurkan partisipasi politik di tingkat daerah untuk terwujudnya stabilitas politik nasional; (b) tujuan ekonomi, yaitu untuk menjamin bahwa pembangunan akan dilaksanakan secara efektif dan efesien di daerah-daerah dalam rangka mewujudkan kesejahteraan sosial.

Desentralisasi, adalah istilah yang luas dan selalu menyangkut persoalan kekuatan (power).Umumnya dihubungkan dengan pendelegasian atau penyerahan wewenang dari pemerintah pusat kepada pejabatnya di daerah, atau kepada lembagalembaga pemerintah di daerah untuk menjalankan urusan-urusan pemerintahan di daerah. Dalam Encyclopedia of the Social Sciences, desentralisasi adalah penyerahan wewenang dari tingkat pemerintahan yang lebih tinggi kepada pemerintahan yang lebih rendah, baik yang menyangkut bidang legislatif, yudikatif maupun administratif. Dalam ensiklopedia tersebut, dikemukakan bahwa desentralisasi adalah kebalikan dari sentralisasi, tetapi jangan dikacaukan dengan pengertian deconcentration, sebab istilah ini secara umum lebih diartikan sebagai pendelegasian dari atasan kepada bawahannya untuk melakukan tindakan atas nama atasannya tanpa melepaskan wewenang dan tanggung jawabnya. 
Kewenangan daerah ini mencakup kewenangan dalam seluruh bidang pemerintahan, kecuali kewenangan yang dikecualikan dalam UU Nomor 23 Tahun 2014 sebagaimana diatur dalam Pasal 10 ayat (1) yaitu kewenangan dalam bidang politik luar negeri, pertahanan dan keamanan, yustisi, moneter dan fiskal nasional dan agama.

\section{Dekonsentrasi}

Indonesia merupakan negara kesatuan, antara pemerintah pusat dan pemerintah daerah mempunyai hubungan yang sangat erat.Dalam hubungannya dengan tugas pemerintahan, pemerintah pusat dapat menyerahkan urusan pemerintahannya kepada daerah secara dekonsentrasi, dan urusan-urusan pemerintahan yang diserahkannya itu tetap menjadi tanggung jawab pemerintah pusat.

Latarbelakang diadakannya sistem dekonsentrasi, adalah tidak semua urusan pemerintah pusat dapat diserahkan pada urusan pemerintah daerah menurut asas desentralisasi. Pertimbangan dan tujuan diselenggarakan asas dekonstrasi ini adalah sebagai berikut:

a. Meningkatkan efesiensi dan efektivitas penyelenggraan pemerintahan, pengelolaan pembangunan dan pelayanan terhadap kepentingan umum;

b. Memelihara komunikasi sosial kemasyarakatan dan sosial budaya dalam sistem administrasi Negara;

c. Memelihara keserasian pelaksanaan pembangunan nasional;

d. Memelihara keutuhan Negara Kesatuan Republik Indonesia.

Dekonsentrasi, adalah pelimpahan wewenang dari pemerintahan atau wilayah atau kepala instansi vertikal tingkat atasnya pada pejabat-pejabat di daerah yang meliputi sebagai berikut:

(1) Pelimpahan wewenang dari aparatur pemerintah yang lebih tingkatannya ke aparatur lain dalam satu tingkatan pemerintahan disebut dekonsentrasi horizontal.

(2) Pelimpahan wewenang dari pemerintah atau dari aparatur pemerintah yang lebih tinggi tingkatannya ke aparatur lain dalam tingkatan pemerintahan yang lebih rendah disebut dekonsentrasi vertikal.

Untuk pelaksanaan asas dekonsentrasi, wilayah Negara Kesatuan Republik Indonesia dibagi dalam wilayah-wilayah provinsi dan ibukota negara. Wilayah provinsi dibagi ke dalam wilayah-wilayah kabupaten dan kota. Wilayah-wilayah kabupaten dan kota dibagi dalam wilayah kecamatan. Penerapan asas dekonsentrasi semacam ini, disebut dekonsentrasi teritorial.Hal itu yang esensial dalam pelaksanaan dekonsentrasi, adalah urusan atau wewenang yang dilimpahkan sepenuhnya menjadi urusan kewenangan pemerintah pusat, sedangkan aparat yang dilimpahkan sebagai pelaksana.

Undang-Undang Nomor 23 Tahun 2014 Pasal 1 ayat (9) menjelaskan bahwa dekonsentrasi adalah pelimpahan wewenang pemerintahan oleh pemerintah kepada 
Gubernur sebagai wakil pemerintah pusat kepada instansi vertikal di wilayah tertentu, dan/atau kepada gubernur dan bupati/walikota sebagai penanggung jawab urusan pemerintahan umum. Dengan demikian, dekonsentrasi merupakan tanggung jawab pemerintah pusat, sedangkan daerah dalam hal ini provinsi diberi wewenang, karena kedudukannya sebagai wakil pemerintah pusat di daerah.Oleh karena itu, gubernur selain pelaksana desentralisasi, juga melaksanakan asas dekonsentrasi.Besaran dan isi dekonsentrasi harus dekat dengan kepentingan masyarakat dan bermakna sebagai upaya mempertahankan dan memperkuat persatuan dan kesatuan bangsa serta keutuhan wilayah Negara Kesatuan Republik Indonesia dan meningkatkan pemberdayaan, menumbuhkan prakarsa dan kreaktivitas masyarakat serta kesadaran nasional.

\section{Tugas Pembantuan}

Tugas pembantuan adalah tugas-tugas untuk turut serta dalam melaksanakan urusan pemerintahan yang ditugaskan kepada pemerintah daerah oleh pemerintah atau pemerintah daerah tingkat atasnya, dengan kewajiban mempertanggung jawabkan kepada yang menugaskan.Urusan yang ditugaskan itu, sepenuhnya merupakan wewenang pemerintah atau provinsi.

Pemerintah atau provinsi yang menugaskan itu menyusun rencana kegiatan atau kebijaksanaan, dan menyediakan anggarannya, sedangkan daerah yang ditugasi hanya melaksanakannya, tetapi dengan kewajiban mempertanggung jawabkan pelaksanaan tugas kepada yang memberikan tugas. Menurut UU Nomor 23 Tahun 2014 Pasal 1 ayat (11) bahwa tugas pembantuan, adalah penugasan dari pemerintah pusat kepada daerah otonom untuk melaksanakan sebagian urusan pemerintahan yang menjadi kewenangan pemerintah pusat, atau dari pemerintah daerah provinsi kepada daerah kabupaten/kota untuk melaksanakan sebagian urusan pemerintahan yang menjadi kewenangan daerah provinsi.

Berdasarkan uraian tersebut di atas, maka hakikat tugas pembantuan adalah sebagai berikut:

(a) Membantu menjalankan urusan pemerintahan dalam tahap implementasi kebijakan yang bersifat operasional.

(b) Urusan pemerintah yang dapat ditugas pembantuan, adalah yang menjadi kewenangan dari institusi yang menugaskannya.

(c) Kewenangan yang dapat ditugas pembantuan, adalah kewenangan yang bersifat atributif, sedangkan kewenangan yang bersifat delegatif tidak dapat ditugas pembantuan pada institusi lain. Kewenangan atributif, adalah kewenangan yang melekat pada satuan pemerintahan atas dasar peraturan perundang-undangan yang membentuknya. Adapun kewenangan delegasi, adalah kewenangan yang didelegasikan dari satuan pemerintah yang lebih tinggi kepada satuan pemerintah yang lebih rendah. Kewenangan delegatif tidak dapat didelegasikan kepada pemerintah lainnya, karena bukan kewenangan yang melekat pada satuan pemerintah yang bersangkutan. 
(d) Urusan pemerintah yang ditugas pembantuan tetap menjadi kewenangan dari institusi yang menugaskannya;

(e) Kebijakan, strategi, pembiayaan, sarana dan prasarana serta sumber daya manusia disediakan oleh institusi yang menugaskannya.

(f) Kegiatan operasional diserahkan sepenuhnya pada institusi yang diberi penugasan sesuai dengan situasi, kondisi, serta kemampuannya.

(g) Institusi yang menerima penugasan diwajibkan melaporkan dan mempertanggung jawabkan mengenai urusan pemerintahan yang dikerjakannya kepada institusi yang menugaskan.

Menurut Peraturan Pemerintah Nomor 52 Tahun 2001 tentang Penyelenggaraan Tugas Pembantuan, maka maksud dan tujuan di adakannya tugas pembantuan, adalah meningkatkan efesiensi dan efektivitas penyelenggaraan pemerintahan, pengelolaan pembangunan, serta pelayanan umum. Begitu juga untuk memperlancar pelaksanaan tugas dan penyelenggaraan permasalahan serta membantu pengembangan pembangunan bagi daerah dan desa.

\section{PENUTUP}

Berdasarkan pembahasan mengenai hakikat otonomi daerah pada sistem ketatanegaraan Indonesia, maka dapat disimpulkan bahwa pada dasarnya otonomi daerah dalam sistem ketatanegaraan di Indonesia adalah kewenangan yang diberikan kepada pemerintah daerah untuk mengatur dan mengurus sendiri urusan pemerintahan dan kepentingan masyarakat sesuai dengan peraturan perundang-undangan yang berlaku.

\section{DAFTAR PUSTAKA}

Abdul Gaffar Karim,2011, Komleksitas Persoalan Otonomi Daerah di Indonesia, Pustaka Pelajar, Yogyakarta

Agus .Santoso, 2013, Menyingkap Tabir Otonomi Daerah di Indonesia, Pustaka Pelajar, Yogyakarta

Ateng Syafrudin, 2002. Menuju Pemerintahan yang Bersih dan Bertanggung Jawab. Bandung, Jurnal Pro Justitia Edisi IV, Universitas Parahyangan.

Irawan Soejito, 1991. Hubungan Pemerintah Pusat dan Pemerintah Daerah. Jakarta, Bina Aksara.

Rozali Abdullah, 2011, Pelaksanaan Otonomi Luas, Jakarta, Radja Grafindo Persada.

Rusdianto Sesung, 2013, Hukum Otonomi Daerah, Bandung, Refika Aditama

Syaukani dkk, 2012, Otonomi Daerah Dalam Negara Kesatuan,Pustaka Pelajar, Yogyakarta.

Utang Rosidin, 2015 ,Otonomi Daerah dan Desentralisasi, Pustaka Setia Bandung. 